\title{
DESCRIPTION OF A NEW SPECIES OF FLOUNDER, CITHARICHTHYS MACROPS, FROM PENSACOLA, FLORIDA.
}

By H. G. DRESEL, Ensign U. S. Navy.

Citharichthys macrops, sp. nov.

The type of this species, No. 21500 in the National Museum collec tion, is a fine example, 5 inches in length, obtained by Mr. Silas Stearns at Pensacola, Fla.

It somewhat resembles C. microstomus Gill, but the mouth is comparatively much larger, the body less elongate, and the scales are different. From C. spilopterus Günther, it differs in the greater height of the body, shorter head, larger scales, and much larger eye.

Description.-The body is suboval; the greatest depth being contained not quite 2 times in the total length to caudal base. The upper profile is very convex, descending in a steep curve from the nape to in front of the upper eye, where it forms an abrupt angle with the short, blunt snout. The mouth is moderate, very oblique, and curved. The maxilla reaches to the vertical through the center of the orbit, its length being contained $2 \frac{1}{2}$ times in the length of the head, and that of the mandible being about one-half of the length of the head. The teeth are minute, in a single series in the jaws, those of the blind side slightly more developed than the others. The eyes are large, separated by a narrow scaleless ridge, which is curved upward and back to the upper angle of the gill-opening. The upper eye is very close to the profile, slightly longer than the lower, its longitudinal diameter being contained $3 \frac{1}{2}$ times in the length of the head, that of the lower eye about 4 times. Their anterior margins are in the same vertical line. The snout is shorter than the eye, its length being one-fifth of that of the head. The gill-rakers are moderate, the longest being about one-half as long as the eye; there are 6 above and 13 below the angle of the anterior arch.

The scales are large, apparently not ciliated. No accessory scales. Each scale is narrowly striated along its middle, and the posterior borders meet in a well-defined obtuse angle, giving a lozenge-shaped appearance to the imbrication. The scales of the pectoral region are somewhat reduced in size. There are 41 scales in the lateral line, 14 transverse rows above and 16 below, at the greatest depth of body ; 13 above and 13 below at the middle of the lateral line. The cheek of the blind side has 8 series of scales.

The dorsal fin begins on the blind side near the tip of the snout. The anterior rays are deeply exserted, the first ray being as long as the eye. The fin is highest at its middle portion, the longest ray being slightly longer than one-half the length of the head. The anal origin is below the axis of the pectoral fin, its distance from the tip of the snout being 
contained $3 \frac{1}{2}$ times in the total length to caudal base. The longest anal ray is slightly longer than the longest dorsal ray. The caudal fin is pointed, the middle caudal ray being one-fourth as long as the total length to caudal base. The pectoral of the eyed side is somewhat longer than that of the blind side, its length being contained 12 times in that of the head. The ventral of the eyed side is inserted on the ridge of the abdomen; it is shorter than that of the blind side, its length being contained $22 \frac{2}{3}$ times in the distance of its origin from the tip of the snont.

The color in spirits is a light olive-brown. The body with some 20 dark brown spots, the largest about as large as the eye. Four of these spots are arranged at equal intervals along the lateral line, the second, near the middle of the latter, being the most prominent. Dorsal and anal fins, with a series of round brown spots, one at the middle of every sixth or seventh ray, besides smaller irregular spots and mottlings. Caudal fin spotted and mottled with dark brown, and with two round brown spots, one above the other, on the basal half of the fin.

Head, 4; depth, 2 . Radial formula: D. 80 ; A. 56. Lateral line, 1441-16.

A table of measurements of C. macrops, C. microstomus, and C. spilopterus is added for comparison.

Table of measurements.

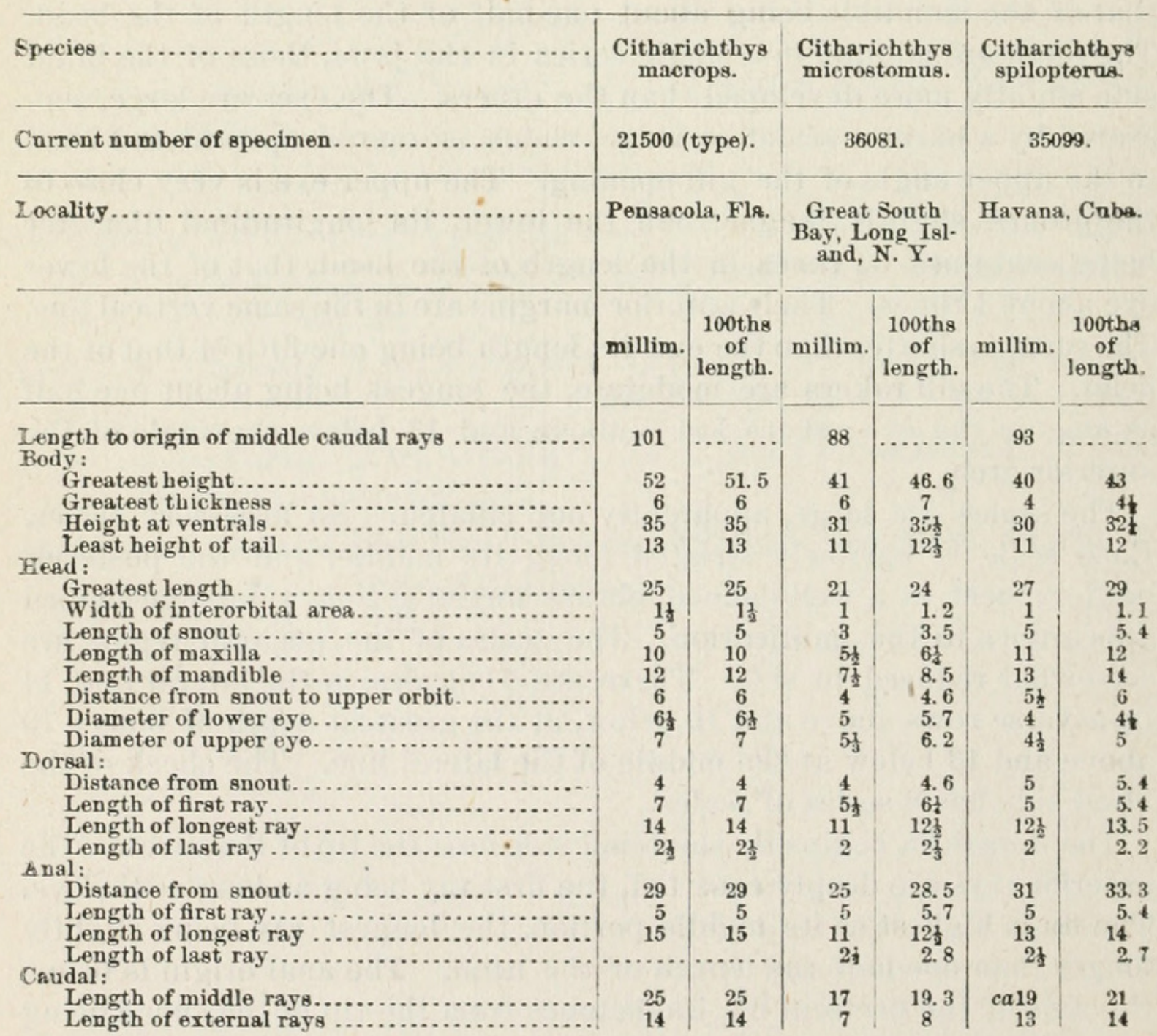


PROCEEDINGS OF UNITED STATES NATIONAL MUSEUM. 541

Table of measurements-Continued.

\begin{tabular}{|c|c|c|c|c|c|c|}
\hline Species ... & \multicolumn{2}{|c|}{$\begin{array}{l}\text { Citharichthys } \\
\text { macrops. }\end{array}$} & \multicolumn{2}{|c|}{$\begin{array}{l}\text { Citharichthys } \\
\text { microstomus. }\end{array}$} & \multicolumn{2}{|c|}{$\begin{array}{l}\text { Citharichthys } \\
\text { spilopterus. }\end{array}$} \\
\hline Carrent number of specimen ...... & \multicolumn{2}{|c|}{21500 (type). } & \multicolumn{2}{|c|}{36081.} & \multicolumn{2}{|c|}{35099.} \\
\hline \multirow[t]{2}{*}{ Locality .. } & \multicolumn{2}{|c|}{ Pensacola, Fla. } & \multicolumn{2}{|c|}{$\begin{array}{l}\text { Great South } \\
\text { Bay, Long Is- } \\
\text { land, N. Y. }\end{array}$} & \multicolumn{2}{|c|}{ Havana, Cuba. } \\
\hline & millim. & $\begin{array}{c}\text { 100ths } \\
\text { of } \\
\text { length. }\end{array}$ & millim. & $\begin{array}{c}100 \text { ths } \\
\text { of } \\
\text { length. }\end{array}$ & millim. & $\begin{array}{c}100 \text { ths } \\
\text { of } \\
\text { length. }\end{array}$ \\
\hline $\begin{array}{l}\text { Pectoral: } \\
\text { Distance from snont...... }\end{array}$ & 25 & 25 & 20 & 22.8 & & \\
\hline Length $\left\{\begin{array}{l}\text { sinistral } \ldots \ldots \ldots \\
\text { dextral ................ }\end{array}\right.$ & 16 & 16 & 16 & 18.4 & 13 & 14 \\
\hline $\begin{array}{l}\text { Ventral: } \\
\text { Distance } \mathrm{fr}\end{array}$ & 12 & 12 & 10 & 11.4 & $11+$ & 12 \\
\hline $\begin{array}{l}\text { Distance from snout........ } \\
\text { Length on blind side ...... }\end{array}$ & $\begin{array}{l}24 \\
10\end{array}$ & $\begin{array}{l}24 \\
10\end{array}$ & $\begin{array}{l}20 \\
10\end{array}$ & $\begin{array}{l}22.8 \\
11.4\end{array}$ & $25 \frac{1}{2}$ & $\begin{array}{r}27.3 \\
8.7\end{array}$ \\
\hline Length on eyed side....................... & 9 & 9 & 9 & 10.3 & 71 & 3 \\
\hline 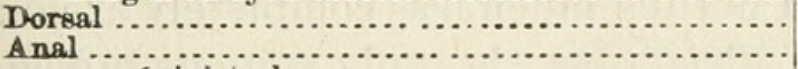 & 80 & ....... & 76 & $\cdots \cdots \cdots$ & $81^{7}$ & \\
\hline 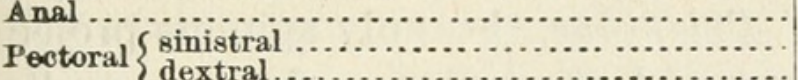 & $\begin{array}{l}56 \\
11\end{array}$ & (n...... & $\begin{array}{l}57 \\
10\end{array}$ & -......... & $\begin{array}{l}62 \\
10\end{array}$ & -......... \\
\hline 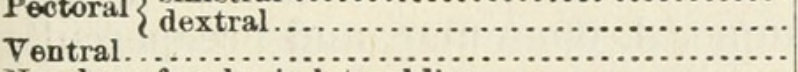 & 9 & $\cdots \cdots$ & $\begin{array}{r}10 \\
9\end{array}$ & $\cdots \cdots$ & $\begin{array}{r}10 \\
9\end{array}$ & (.......... \\
\hline 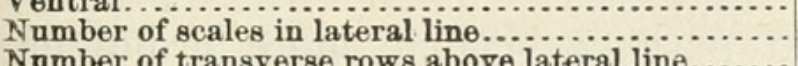 & $\begin{array}{r}6 \\
41\end{array}$ & an. & $\begin{array}{r}6 \\
41\end{array}$ & $\cdots$ & $\begin{array}{r}6 \\
46\end{array}$ & $\begin{array}{ll}2 \ldots \\
\cdots \cdots \cdots\end{array}$ \\
\hline $\begin{array}{l}\text { Number of transverse rows above lateral line....... } \\
\text { Number of transverse rows below lateral line...... }\end{array}$ & 14 & $\cdots \cdots$ & 10 & & ... & (n......... \\
\hline 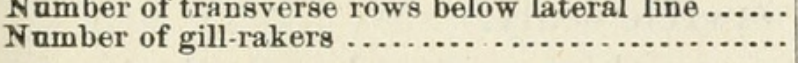 & $6+13$ & & $\begin{array}{r}14 \\
4+6\end{array}$ & & $\dddot{5}+10$ & $\ldots \ldots$ \\
\hline
\end{tabular}

November 26, 1884.

\section{DESCRIPTION OF THREE NEW SPECIES OF FISHES (PRIONOTUS STEARNSI, PRIONOTUS OPHRYAS, AND ANTHIAS VIVANUS) COLLECTED AT PENSACOLA, FLORIDA, BY MR. SILAS STEARNS.}

\section{BY DAVID S. JORDAN RAd JOSEPH SWAIN.}

Prionotus stearnsi, sp. nov. (No. 36943.)

Head $2 \frac{2}{3}$ in length ( $3 \frac{1}{3}$ including caudal); depth $4(5) ;$ D. VIII -12 ; A. 12. Scales (transverse series), 77 ; pores in lateral line about 48 . Inength, $3 \frac{3}{8}$ inches.

Allied to Prionotus evolans.* Body not very slender; narrowed but compressed above, the width of the nape between the occipital spines being about one-fifth the head. Head depressed and long, its upper profile being a little concave before eye, thence slightly convex or almost straight to front of dorsal. Snout $2 \frac{1}{2}$ in head, not very broad, rather more than usually rounded anteriorly and scarcely emarginate at tip. Edges of snout without spine and without distinct serræ, the margin merely granular. Surfaces of bones of head comparatively smooth, but roughened with small granules, which are arranged in radiating striæ, much as in $P$. evolans, but more regularly than in that species.

* Prionotus sarritor Jordan \& Gilbert, Proc. U. S. Nat. Mus., 1882, 615. The type of Trigla evolans L. in London has been examined by Dr. Bean. It is apparently identical with $P$. sarritor. 


\section{$2 \mathrm{BHL}$ Biodiversity Heritage Library}

Dresel, H. G. 1885. "Description of a new species of flounder, Citharichthys macrops, from Pensacola, Florida." Proceedings of the United States National Museum 7(464), 539-541. https://doi.org/10.5479/si.00963801.464.539.

View This Item Online: https://www.biodiversitylibrary.org/item/31798

DOI: https://doi.org/10.5479/si.00963801.464.539

Permalink: https://www.biodiversitylibrary.org/partpdf/11591

\section{Holding Institution}

Smithsonian Libraries

\section{Sponsored by}

Smithsonian

\section{Copyright \& Reuse}

Copyright Status: NOT_IN_COPYRIGHT

This document was created from content at the Biodiversity Heritage Library, the world's largest open access digital library for biodiversity literature and archives. Visit BHL at https://www.biodiversitylibrary.org. 